\title{
Anxiety Caused by Traumatic Brain Injury Correlates to Decreased Prefrontal Cortex VEGF Immunoreactivity and Neuron Density in Immature Rats
}

\author{
İmmatür Szçanlarda Travmatik Beyin Hasarmm Neden Olduğu \\ Anksiyete, Prefrontal Korteks VEGF İmmunreaktivitesi ve Nöron \\ Dansitesinde Azalma ile Koreledir
}

Basak BAYKARA ${ }^{1}$, Ferihan CETIN ${ }^{2}$, Burak BAYKARA ${ }^{3}$, Ilkay AKSU², Ayfer DAYI ${ }^{2}$, Muge KIRAY², Ali Rıza SISMAN ${ }^{4}$, Durgul OZDEMIR ${ }^{5}$, Mehmet Nuri ARDA ${ }^{6}$, Nazan UYSAL ${ }^{2}$

${ }^{1}$ Dokuz Eylul University, Faculty of Physical Therapy and Rehabilitation, Department of Histology and Embryology, Izmir, Turkey

${ }^{2}$ Dokuz Eylul University, Faculty of Medicine, Department of Physiology, Izmir, Turkey

${ }^{3}$ Dokuz Eylul University, Faculty of Medicine, Department of Child and Adolescent Psychiatry, Izmir, Turkey

${ }^{4}$ Dokuz Eylul University, Faculty of Medicine, Department of Biochemistry, Izmir, Turkey

${ }^{5}$ Dokuz Eylul University, Faculty of Medicine, Department of Pediatrics, Izmir, Turkey

${ }^{6}$ Dokuz Eylul University, Faculty of Medicine, Department of Neurosurgery, Izmir, Turkey

Correspondence address: Basak BAYKARA / E-mail: basak.baykara@deu.edu.tr

\begin{abstract}
AIM: Traumatic brain injury (TBI) may cause neuropsychiatric disorders such as anxiety disorder which has negative effects on cognitive functions and behavior. The aim of this study is to investigate the effects of TBI on anxiety and vascular endothelial growth factor (VEGF) immunoreactivity on the prefrontal cortex of immature rats, which is one of the anxiety-related regions of the brain in 7-day-old immature rats subjected to contusion injury.

MATERIAL and METHODS: Rats were divided into three groups: Control $(n=7)$, Sham $(n=7)$ and TBI $(n=7)$. Anxiety levels were assessed with open field activity and elevated plus maze in postnatal 27 days. Prefrontal cortex damage related to TBI was examined by cresyl violet staining and VEGF immunostaining. Prefrontal cortex neuronal density was calculated. Serum corticosterone levels were determined.

RESULTS: The anxiety level in the TBI group was significantly greater than the control and sham groups. The prefrontal cortex VEGF immunostaining score and neuron density were decreased in the TBI group compared to control and sham group. Serum corticosterone levels were significantly increased in the TBI group.
\end{abstract}

CONCLUSION: These results indicate that TBI decreases VEGF immunoreactivity in prefrontal cortex neurons and increases the anxiety levels of immature rats.

KEYWORDS: Traumatic brain injury, Immature rat, Anxiety, VEGF, Prefrontal cortex

öz

AMAÇ: Travmatik beyin hasarı (TBH), bilişsel işlevler ve davranışları üzerinde olumsuz etkileri vardır. Anksiyete bozukluğu gibi nöropsikiyatrik hastalıklara neden olabilir. Bu çalışmanın amacı, 7 günlük sıçanlara uygulanan TBH'nin anksiyete düzeyleri, prefrontal kortekste nöron dansitesi ve vasküler endotelyal büyüme faktörü (VEGF) immünoreaktivitesi üzerine olan etkilerini araştırmaktır.

YÖNTEM ve GEREÇLER: Sıçanlar üç gruba ayrıldı: Kontrol $(n=7)$, Sham $(n=7)$ ve TBH $(n=7)$. Anksiyete düzeyleri, doğum sonrası 27 gün içinde açık alan aktivitesi ve yükseltilmiş artı labirent ile değerlendirildi. Prefrontal korteks, cresyl violet ve VEGF immün boyaması ile incelendi. Prefrontal korteks nöronal yoğunluğu hesaplandı. Serum kortikosteron düzeyleri belirlendi.

BULGULAR: TBH grubunda anksiyete düzeyi kontrol ve sham gruplarına göre anlamlı derecede daha fazlaydı. Prefrontal korteks VEGF immünreaktivitesi ve nöron yoğunluğu kontrol ve sham grubu ile karşılaştırıldığında TBH grubunda azalmış olarak bulundu. Serum kortikosteron düzeyleri TBH grubunda anlamlı derecede artmış bulundu.

SONUÇ: Bu sonuçlar immatür sıçanlarda TBH'ın, anksiyete düzeylerini arttırdığını, prefrontal korteks nöron dansitesi ve VEGF immünoreaktivitesini azalttığını göstermektedir.

ANAHTAR SÖZCÜKLER: Travmatik beyin hasarı, İmmatür sıçan, Anksiyete, VEGF, Prefrontal korteks 


\section{INTRODUCTION}

Head trauma is a leading cause of death and disability in childhood $(1,17)$. Although children with head trauma have better survival rates as compared with adults, the long-term sequelae and consequences are often more devastating in children due to their age and developmental level. Cognitive deficits are well-known sequelae of traumatic brain injury (TBI) that lead to long-term functional impairment and decrease in quality of life $(11,26,27)$. In recent years, psychiatric disorders such as depression, anxiety disorders, and personality changes was seen following TBI $(15,24,32,40)$.

Anxiety is worry about the future state of arousal with the feeling of non-specific threat (31). It was shown that amygdala and prefrontal cortex (PFC) are critical for emotion expressions such as fear and anxiety. PFC is controlled and organized via the output of the amygdala $(16,30)$. TBI may cause anxiety-like behaviors by causing structural changes in the brain $(12,18)$. TBI also decreases the neurotrophic factor levels such as vascular endothelial growth factor (VEGF) in the PFC which is known as anxiolytic. The change in VEGF levels alters the cell proliferation and maturation in the brain region such as PFC (38).

Two brain structures such as cortex and the hippocampus is prominently affected in TBI (37). Hippocampus-related learning is well studied in immature rats with TBI $(26,27)$; however there are few studies about experimental TBIinduced anxiety in rats. In Jones et al. study, experimental TBI has been reported to trigger anxiety-like behavior in adult rats (14). However the mechanisms of TBI induced anxiety is not well known.

The immature brain is exceedingly vulnerable to apoptotic neurodegeneration triggered by head trauma $(3,4)$. This developmental vulnerability period coincides with the brain growth spurt period, which occurs in the first two postnatal weeks in the rats and in the first 2 years old in humans (9).

The aim of this study is to investigate the effects of TBI on the anxiety levels of the immature rats in preadolescent period, and on the PFC VEGF immunoreactivity.

\section{MATERIAL and METHODS}

\section{Animals and Experimental Design}

All experiments were performed in accordance with the guidelines provided by the Experimental Animal Laboratory and approved by the Animal Care and Use Committee of the Dokuz Eylul University, School of Medicine. Wistar Albino rats with dated pregnancies were maintained at the same center and housed in individual cages with free access to water and laboratory chow. Forty-two litters delivered spontaneously were reared with their dams until the time of experimentation at 7 days of postnatal age. All rats were maintained on a constant 12-h-light/dark cycle at constant room temperature $\left(21^{\circ} \mathrm{C}\right)$, and humidity $(60 \%)$. Rats were divided into three groups: Control $(n=7)$, Sham ( $n=7), \operatorname{TBI}(n=7)$.
We used a modification of a well-described percussion trauma model in immature rats, in an attempt to model infant and early childhood head trauma (3). The contusing device consisted of a hollow tube $40 \mathrm{~cm}$ long, perforated at $1-\mathrm{cm}$ intervals to prevent air compression. The device was kept vertical to the surface of the skull and guided a falling weight onto a circular footplate resting upon the surface of the parietal bone. The center of the footplate was stereotaxically positioned $3 \mathrm{~mm}$ anterior and $2 \mathrm{~mm}$ lateral to the lambda and was fixed in place under ether anesthesia. A force of $160 \mathrm{~g} \mathrm{~cm}$ produced by a 10-g weight was selected to produce brain contusion. Experiments were carried out between 9.00 and 11.00 am in a sound-attenuated and air-regulated experimental room. All the immature rats were kept on a heating pad until returned to their mothers at $4 \mathrm{~h}$ after the trauma or sham surgery.

The remaining rats were weaned on day 22 and when the immature rats were 24 days old, their anxiety levels were evaluated using the open field and elevated plus maze tests. The recording and analysis of the anxiety levels were performed with the HVS image video tracking system.

\section{Behavioral tests}

Locomotor activity was measured with an open-field test; $1 \mathrm{~m} \times 1 \mathrm{~m}$ and $50 \mathrm{~cm}$ in height, video camera installed $2.5 \mathrm{~m}$ above apparatus. Each rat was placed in the center of the open-field and then locomotor activity (ambulation) was measured for $5 \mathrm{~min}$ in a sound-proof observation room illuminated with controlled light (100 lx).

The immature rats were tested for anxiety behavior in the elevated plus maze. This consisted of a central platform (5 $\mathrm{cm} \times 5 \mathrm{~cm}$ ) with two open arms $(50 \mathrm{~cm}$ long, $10 \mathrm{~cm}$ wide and $0.5 \mathrm{~cm}$ high borders) and two closed arms (same dimensions as the open arms only with $40 \mathrm{~cm}$ high walls) that were elevated $50 \mathrm{~cm}$ above the ground. Immature rats were placed on the platform facing the open arm and were observed for $5 \mathrm{~min}$. The total number of entries into the open and closed arms as well as the time spent in the open and closed arms was measured.

\section{Light Microscopic Examination}

At the end of the behavior tests (postnatal 27 days), after a light ether anesthesia, the bloods of the subjects were drawn, and the PFC regions were separated after removing the brain tissue. PFC tissues were removed and fixed in $10 \%$ formalin in phosphate buffer for $24 \mathrm{~h}$. The PFC was sectioned coronally into sequential $5 \mu \mathrm{m}$ sections using a microtome. Each sample was subjected to the estimation of neuron density by taking three coronal sections through the prefrontal cortex that corresponded approximately to plates 9,11 in the rat atlas of Paxinos and Watson. All sections were stained by cresyl violet. The images were analyzed by using a computer assisted image analyzer system consisting of a microscope (Olympus BX-51 Tokyo, Japan) equipped with a high-resolution video camera (Olympus DP71, Japan). The numbers of neurons in these regions were counted in $40 \mathrm{X}$ mag. by a $16800 \mu \mathrm{m}^{2}$ counting frame. The counting frame was placed randomly 
three times on the image analyzer system monitor and the numbers of neurons were counted and the average was taken. PFC neuron density was calculated.

\section{Immunohistochemical Assesment}

Immunohistochemical staining was performed using the streptavidin/biotin method. The immunohistochemistry procedure for VEGF was performed. Tissue sections were incubated at $60^{\circ} \mathrm{C}$ overnight then dewaxed in xylene for 30 min. After rehydrating through a decreasing series of alcohol, sections were washed in distilled water for $10 \mathrm{~min}$. They were then treated with $10 \mathrm{mM}$ citrate buffer (AP-9003-125, Labvision) at $95^{\circ} \mathrm{C}$ for five minutes, to unmask antigens by heat treatment. Then slides washed in deionized water three times for two minutes. Sections were delineated using a Dako pen (Dako, Glostrup, Denmark) and incubated in a solution of $3 \% \mathrm{H}_{2} \mathrm{O}_{2}$ for 15 min to inhibit endogenous peroxidase activity. They were then incubated with normal serum blocking solution for 30 minutes. Sections were incubated in a humid chamber for overnight at $+4^{\circ} \mathrm{C}$ with antibodies to: VEGF $(1 / 100$ dilution: SC-7629, Santa-Cruz biotechnology). For negative controls, distilled water was used in place of the primary antibodies. They were washed three times for $5 \mathrm{~min}$ each with PBS, followed by incubation with biotinylated IgG and then with streptavidin-peroxidase conjugate (Zymed 85-9042, CA). After washing three times for 5 min with PBS, sections were incubated with DAB substrate containing diaminobenzidine (Zymed 00-2020, CA) for 5 min to detect immunoreactivity and then with Mayer's hematoxylin. Sections were covered with mounting medium.. Three PFC sections were used for each sample in performing the immunohistochemical scoring. The qualitative intensity of staining for VEGF was assessed using a scale between 0 and +++ . With 0 representing no detectable stain and +++ representing strongest stain.

\section{Measurement of Serum Corticosterone Levels}

The serum corticosterone levels were measured with original Siemens kits in Siemens Immulite 2000 XPi device with chemiluminesence immunoassay protocol.

\section{Statistical Analysis}

All statistical procedures were performed by SPSS software for Windows, Version 11.0 (SPSS, Chicago, IL, USA). Differences in the anxiety tests results, density of neurons, VEGF immune staining scores and serum corticosterone levels between groups were tested by ANOVA and post hoc comparisons were made by Bonferroni correction. Correlations among groups were calculated using Pearson correlation analysis. Results are presented as mean \pm S.E.M. A value of $p<0.05$ was considered statistically significant.

\section{RESULTS}

The moving time in the immature rats with TBI and their total entries into centre cells were significantly reduced $(p<0.05)$ when compared to sham and control groups (Figures 1A, B). Immature rats with TBI were significantly less active in the open field test $(p<0.05)$. Immature rats with TBI spent significantly more time in the closed arms and spent significantly less time in the open arms of elevated plus maze test $(p<0.05)$ (Figure $2 A, B)$.

The density of neurons was significantly decreased in the contralateral and ipsilateral PFC in immature rats with TBI when compared with sham and control groups $(p<0.001)$ (Figure $3 \mathrm{~A}, \mathrm{~B}$ ). Immunostaining of VEGF was significantly decreased in PFC of immature rat with TBI $(p<0.001)$ (Figure 4 , Table I). There was no statistically difference in contralateral and ipsilateral cortex results.

The basal corticosterone levels of the immature rats with $\mathrm{TBI}$ were significantly higher when compared to sham and control immature rats $(p<0.001)$ (Figure 5).

There was a very strong positive correlations between PFC neuron densities and the amount of time spent in open field arena (right PFC, $r=0,783, p=0.000$; left $P F C, r=0,888, p=0.000$ ). Also, there was a very strong positive correlations between PFC neuron densities and the time spent in the open arms of elevated plus maze test configuration (right PFC, $r=0,901$, $p=0.000$; left PFC, $r=0,886, p=0.000$ ).

In addition, there was a strong positive correlation between PFC VEGF immunostaining score and the time spent in the open arms of elevated plus maze test configuration $(r=0,744$, $\mathrm{p}=0.001$ ) and a strong negative correlation between PFC VEGF immunostaining score and the time spent in the closed arms of elevated plus maze test configuration ( $r=-0,647, p=0.009)$. Also, there was a strong positive correlation between PFC
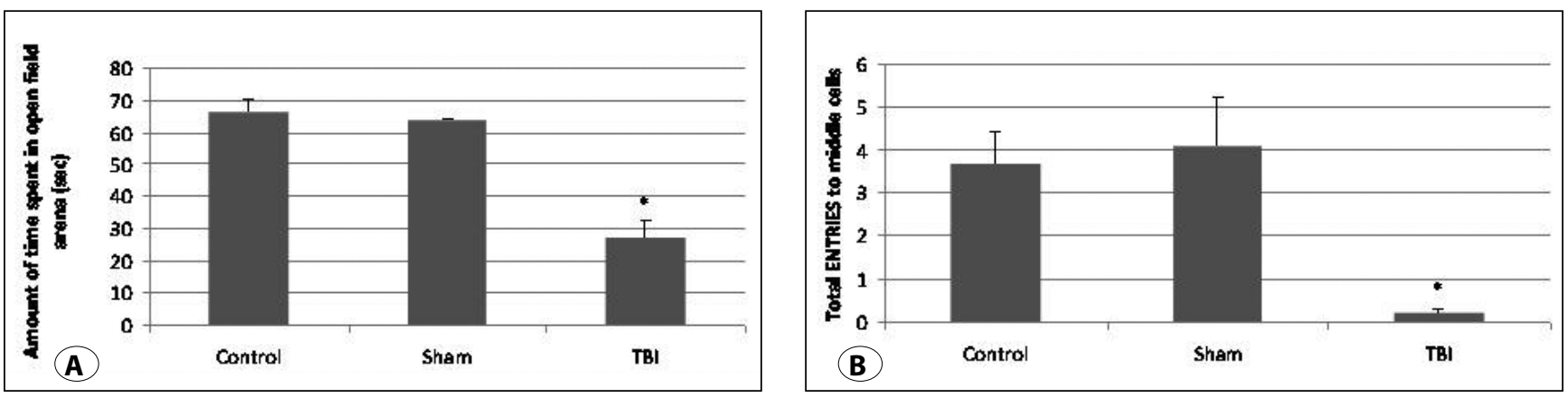

Figure 1: Open field test results; $\mathbf{A}$ ) Percentage of the time they are moving the open field arena, B) Number of entries in the open field arena in the middle cells. ${ }^{*} p<0.05$ compared with the control and sham group. (TBI: Traumatic brain injury). 

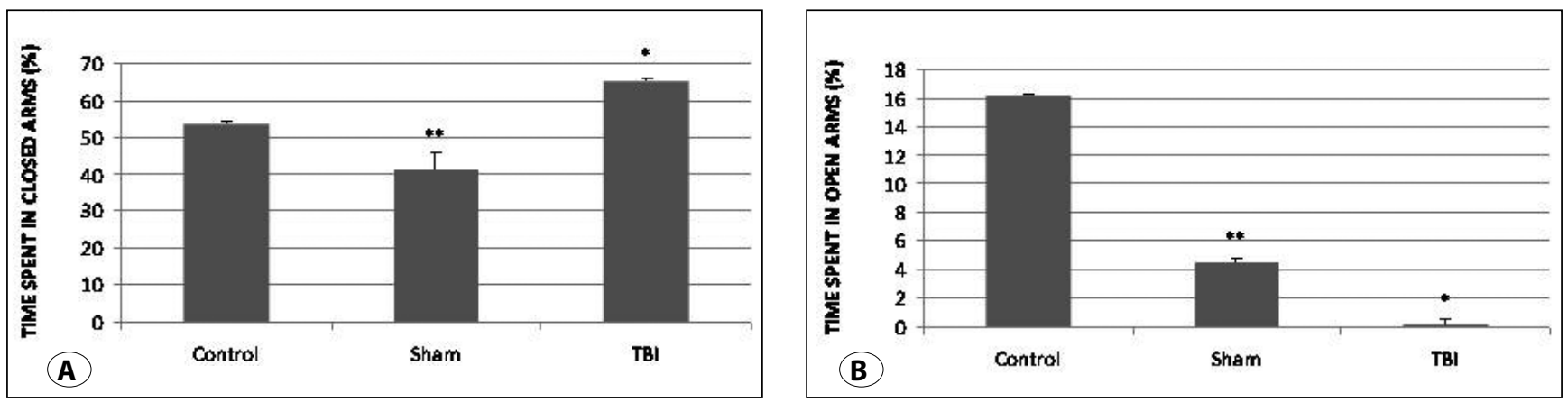

Figure 2: Elevated plus maze test results; ${ }^{*} \mathrm{p}<0.05$ compared with the control and sham group; ${ }^{*} \mathrm{p}<0.05$ compared with the control and TBI group. (TBI: Traumatic brain injury).

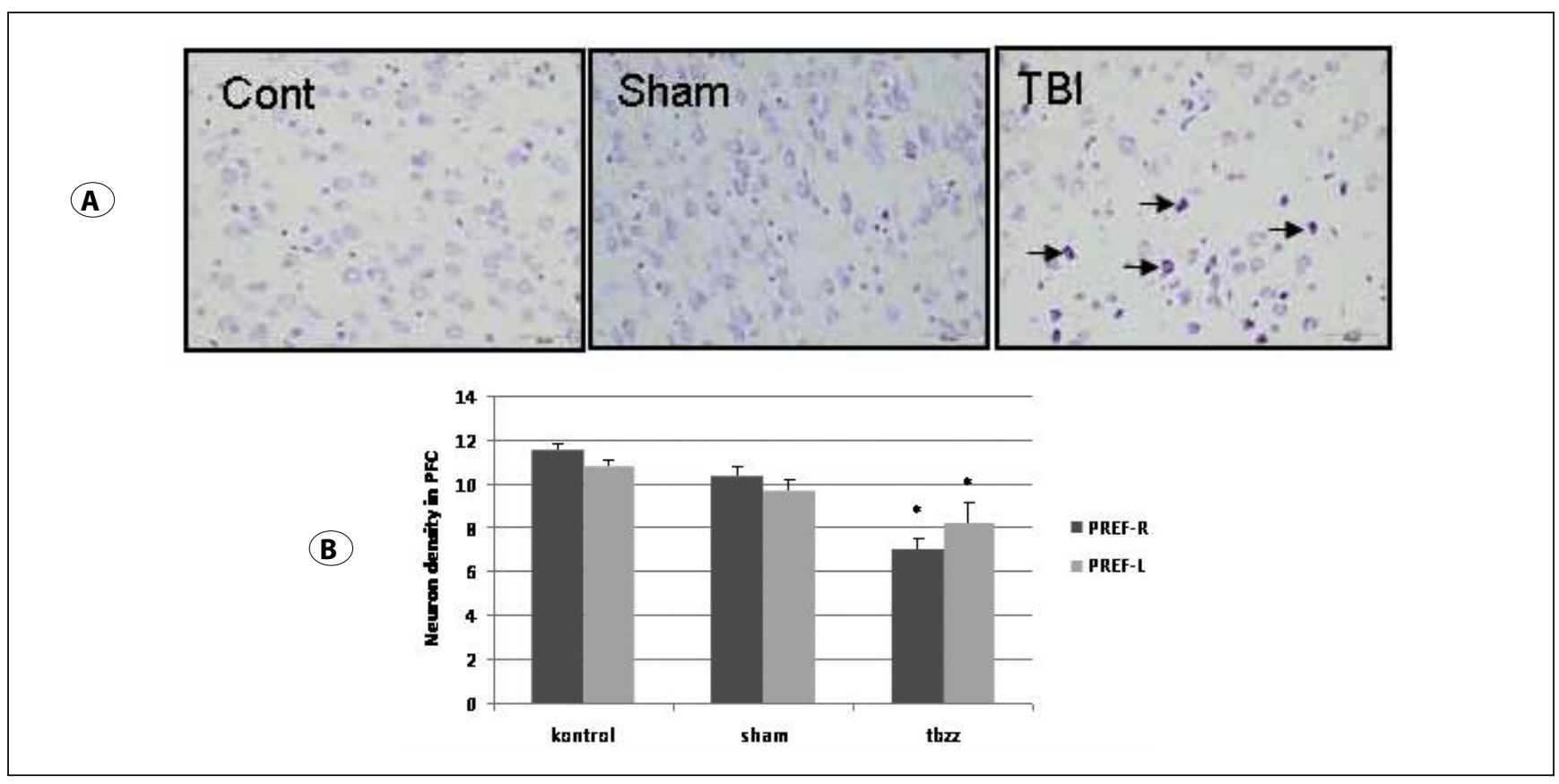

Figure 3: A) Representative photomicrographs of cresyl-violet stained sections of the prefrontal cortex in all groups. Morphologically normal neuron in control (Cont) and sham group. Morphologically damaged neurons (black arrows) in traumatic brain injury group (TBI). B) The density of neurons was significantly decreased in the contralateral and ipsilateral PFC in immature rats with TBI when compared with sham and control groups. ( $\left.{ }^{*} p<0.001\right)$ There was no statistically difference in contralateral and ipsilateral cortex neuron density. ( $p>0.05)$.

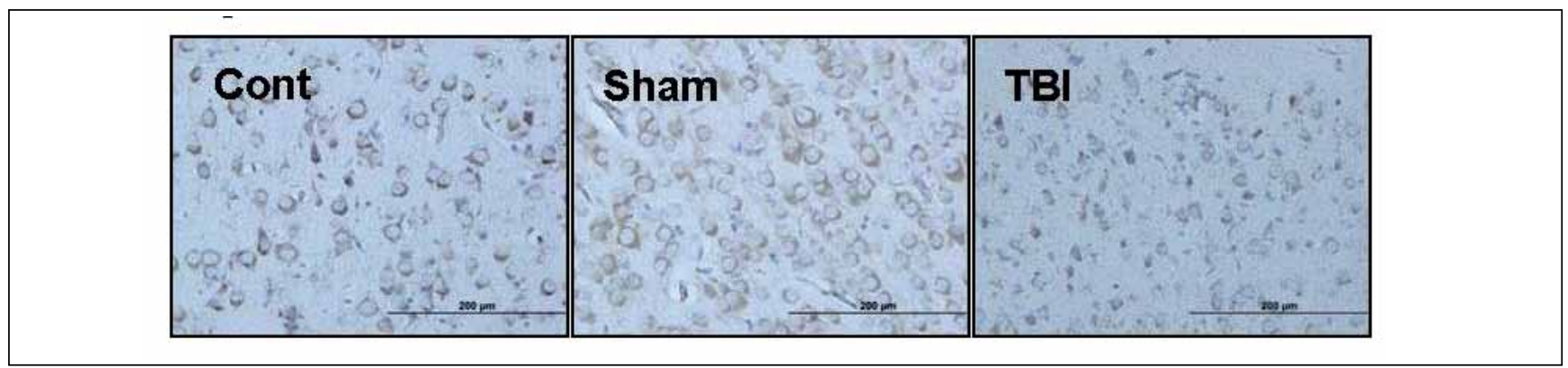

Figure 4: Immunostaining of VEGF in prefrontal cortex sections. Control (Cont) and sham groups were strongly stained; whereas traumatic brain injury (TBI) group was mildly stained on prefrontal cortex. 
Table I: Semiquantitative Analysis of VEGF Immunoreactive Neurons in the Immature Rat Prefrontal Cortex. Traumatic Brain Injury Group Significantly Differed both Other Groups $(p<0.001)$

\begin{tabular}{l|c|c|c|c}
\multirow{2}{*}{ Group } & \multicolumn{4}{|c}{ VEGF immunostaining scores } \\
\cline { 2 - 5 } & None & Mild & Moderate & Strong \\
\hline Control & 0 & 0 & 2 & 6 \\
\hline Sham & 0 & 0 & 0 & 5 \\
\hline Traumatic brain injury & 3 & 4 & 0
\end{tabular}

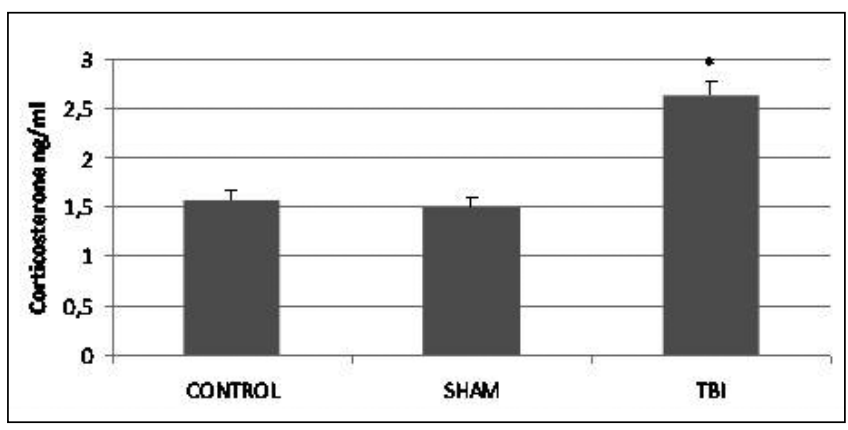

Figure 5: Basal blood corticosteroid levels; ${ }^{*} \mathrm{p}<0.05$ compared with the other groups (TBI: Traumatic brain injury).

VEGF immunostaining score and total entries into centre cells $(r=0,744, p=0.001)$, and a strong positive correlation between PFC VEGF immunostaining score and the moving time in the open field arena $(r=0,861, p=0.000)$.

\section{DISCUSSION}

In this study, it was found that anxiety levels were increased in the immature rats with TBI. Immature rats with TBI had not exploring behaviors (spent less time in the open arms of elevated plus maze test instrument, less moving time and less enters centre cells of open field arena). We also observed that, the neuron densities and VEGF immunostaining were decreased in PFC of immature rats with TBI. To our knowledge, this is the first study that indicated the relationship between VEGF and prefrontal neuronal density and anxiety levels in immature rats with TBI.

It is well known that, the TBI causes behavioral and neuroendocrine differences seen in anxiety disorders $(12,18,21)$. We found that the anxiety levels were increased in immature rats with TBI. In this study, we observed that the locomotor activities of immature rats with TBI decreased in open field test, and they spent less time in the open arms of elevated plus maze. Open field and elevated plus maze tests are devices widely used in testing the anxiety levels in rodents.

It is known that, the PFC controls the emotional and stress responses. In previous studies, it was showed that people with a damaged PFC had problems in emotional regulation in both daily settings and in laboratory tests. In frontal disinhibition syndrome, it is seen that the individuals experience emotional bursts which were disproportionate to the provocation and take excessive risks (2). It was demonstrated that the PFC inhibits the autonomous and endocrine response to stress, and reduce anxiety. In PFC damage, the inhibition of psychological and physiological responses to stress disappears (29). In previously studies, immature rats with TBI display greater anxiety-like behaviors than sham treated rats, and there was no correlations between anxiety-like behaviors and the structural or metabolic changes seen in the amigdala (21).

$\mathrm{TBI}$ is causes alteration of the hypothalamus-pituitary-adrenal axis (HPA) $(5,41)$. Plasma cortisol levels increase after mild to moderate brain injury in the early post-injury period, whereas cortisol levels are depressed after a severe injury $(7,33)$. Little is known about neuroendocrine alterations in chronic period of TBI. Recently, HPA response was enhanced and prolonged in the long-term of adult TBI rat model $(36,18)$. In this study, corticosteroid levels increased in 3 weeks after head trauma in immature rats. Also, in our trauma model was a mild head trauma (3). It was also found that glucocorticoid receptor expression increased in TBI rats, which is indicated as affected negative feedback (22). Chronically elevated levels of corticosterone can adversely affect the neurogenesis and causes loss of synapses $(6,35)$. High levels of corticosterone, during the development of dopaminergic system, can cause permanent behavioral changes by altering dopamine transmission in the mesocorticolimbic regions of the brain $(20,23)$. Activation of the mesocortical dopaminergic path has a significant role in the pathophysiology of mood disorders such as anxiety disorder (13). Thus, the balanced dopamine level may be considered to be useful in treating diseases such as anxiety disorder, in which the dopamine transmission is increased. TBI increases the dopaminergic activity in PFC and striatum of immature rats (39). PFC regulates the secretion of dopamine from the mesocortical projection system (10). Dopamine secretion from the PFC was related to the regulation of anxiety and fear (28).

The release and up-regulation of endogenous neurotrophic factors is a most important mechanism in neuronal repair after brain damage (8). VEGF was shown to be up-regulated parallel with hippocampal neurogenesis in acute period after $\mathrm{TBI}$ (19). There are no data on VEGF in late period of TBI. In our study, VEGF immunostaining was decreased in late period of immature rats with $\mathrm{TBI}$ in $\mathrm{PFC}$, which is an important brain region in anxiety disorders. Angiotrophic and neurotrophic factors both have role in the pathophysiology of psychiatric diseases. VEGF signal irregularities has been detected in anxious individuals (25). The VEGF has protective effects on 
the dopaminergic neurons (34). In this study, the decreased VEGF, might have affected the dopaminergic neurons, which have regulatory effects on anxiety and fear. Also we found that there is a very strong positive correlation between the VEGF immunostaining score levels and open field and elevated plus maze test results.

In conclusion, TBI decreases the prefrontal neuron density and VEGF immunostaining scores thus causes increase in the anxiety levels of immature rats. Further studies are needed to elucidate the role of anxiety and VEGF on the TBI induced changes in dopamine metabolism.

\section{REFERENCES}

1. Adelson PD, Kochanek PM: Head injury in children. J Child Neurol 13:2-15, 1998

2. Bishop S, Duncan J, Brett M, Lawrence AD: Prefrontal cortical function and anxiety: Controlling attention to threat-related stimuli. Nat Neurosci 7:184-188, 2004

3. Bittigau $P$, Sifringer $M$, Pohl $D$, Stadthaus $D$, Ishimaru $M$, Shimizu H, Ikeda M, Lang D, Speer A, Olney JM, Ikonomidou C: Apoptotic neurodegeneration following trauma is markedly enhanced in the immature brain. Ann Neurol 45:724-735, 1999

4. Bittigau $P$, Sifringer $M$, Felderhoff-Mueser $U$, Ikonomidou C: Apoptotic neurodegeneration in the context of traumatic injury to the developing brain. Exp Toxicol Pathol 56:83-89, 2004

5. Bouzarth WF, Shenkin HA, Feldman W: Adrenocortical response to craniocerebral trauma. Surg Gynecol Obstet 126:995-1001, 1968

6. Brummelte S, Galea L: Chronic high corticosterone reduces neurogenesis in the dentate gyrus of adult male and female rats. Neuroscience 168: 680-690, 2010

7. Cernak I, Savic VJ, Lazarov A, Joksimovic M, Markovic S: Neuroendocrine responses following graded traumatic brain injury in male adults. Brain Injury 13:1005-1015, 1999

8. Conte V, Royo C, Shimizu S, Saatman KE, Watson D, Graham DI, Stocchetti N, McIntosh T: Neurotrophic factors, pathophysiology, and therapeutic applications in traumatic brain injury. European Journal of Trauma 29:335-355, 2003

9. Dobbing J and Sands J: Comparative aspects of the brain growth spurt. Early Hum Dev 3:79-83, 1979

10. Goldstein LE, Rasmusson AM, Bunney BS, Roth RH: Role of the amygdala in the coordination of behavioral, neuroendocrine, and prefrontal cortical monoamine responses to psychological stress in the rat. Journal of Neuroscience 16:4787-4798, 1996

11. Hawthorne G, Gruen RL, Kaye AH: Traumatic brain injury and long-term quality of life: findings from an Australian study. J Neurotrauma 26:1623-1633, 2009

12. Hoffman SW, Harrison C: The interaction between psychological health and traumatic brain injury: A neuroscience perspective. Clin Neuropsychol 23:1400-1415, 2009
13. Jahng JW, Ryu V, Yoo SB, Noh SJ, Kim JY, Lee JH: Mesolimbic dopaminergic activity responding to acute stress is blunted in adolescent rats that experienced neonatal maternal separation. Neuroscience 171:144-152, 2010

14. Jones NC, Cardamone L, Williams JP, Salzberg MR, Myers D, O'Brien TJ: Experimental traumatic brain injury induces a pervasive hyperanxious phenotype in rats. J Neurotrauma 25:1367-1374, 2008

15. Jorge RE, Robinson RG, Starkstein SE, Arndt SV:Depression and anxiety following traumatic brain injury. J Neuropsychiatry Clin Neurosci 5:369-374, 1993

16. Kim MJ, Whalen PJ: The structural integrity of an amygdalaprefrontal pathway predicts trait anxiety. J Neurosci 29:11614-11618, 2009

17. Koskiniemi M, Kyykka T, Nybo T, Jarho L: Long-term outcome after severe brain injury in preschoolers is worse than expected. Arch Pediatr Adolesc Med 149: 249-254, 1995

18. Kwon SK, Kovesdi E, Gyorgy AB, Wingo D, Kamnaksh A, Walker $J$, Long JB, Agoston DV: Stress and traumatic brain injury: A behavioral, proteomics, and histological study. Front Neurol 2:12, 2011

19. Laird MD, Vender JR, Dhandapani KM: Opposing roles for reactive astrocytes following traumatic brain injury. Neurosignals 16:154-164, 2008

20. Liu D, Diorio J, Tannenbaum B, Caldji C, Francis D, Freedman A, Sharma S, Pearson D, Plotsky PM, Meaney MJ: Maternal care, hippocampal glucocorticoid receptors, and hypothalamicpituitary-adrenal responses to stress. Science 277:1659-1662, 1997

21. Liu YR, Cardamone L, Hogan RE, Gregoire MC, Williams JP, Hicks RJ, Binns D, Koe A, Jones NC, Myers DE, O'Brien TJ, Bouilleret V: Progressive metabolic and structural cerebral perturbations after traumatic brain injury: An in vivo imaging study in the rat. J Nucl Med 51:1788-1795, 2010

22. McCullers DL, Sullivan PG, Scheff SW, Herman JP: Traumatic brain injury regulates adrenocorticosteroid receptor mRNA levels in rat hippocampus. Brain Res. 947:41-49, 2002

23. McIntosh JL, Hong EK, Sapolsky RM: Glucocorticoids may alter antioxidant enzyme capacity in the brain: Baseline studies. Brain Res 791:209-214, 1998

24. Moore EL, Terryberry-Spohr L: Hope DA: Mild traumatic brain injury and anxiety sequelae: A review of the literature. Brain Inj 20:117-132, 2006

25. Ognibene E, Adriani W, Caprioli A, Ghirardi O, Ali SF, Aloe L, Laviola G: The effect of early maternal separation on brain derived neurotrophic factor and monoamine levels in adult heterozygous reeler mice. Prog Neuropsychopharmacol Biol Psychiatry 32:1269-1276, 2008

26. Ozdemir D, Tugyan K, Uysal N, Sonmez U, Sonmez A, Acikgoz O, Ozdemir N, Duman M, Ozkan H: Protective effect of melatonin against head trauma-induced hippocampal damage and spatial memory deficits in immature rats. Neurosci Lett 385:234-239, 2005 
27. Ozdemir D, Baykara B, Aksu I, Kiray M, Sisman AR, Cetin F, Dayi A, Gurpinar T, Uysal N, Arda MN: Relationship between circulating IGF-1 levels and traumatic brain injury-induced hippocampal damage and cognitive dysfunction in immature rats. Neurosci Lett 507:84-89, 2012

28. Pezze MA, Feldon J: Mesolimbic dopaminergic pathways in fear conditioning. Prog Neurobiol 74:301-320, 2004

29. Porritt MJ, Batchelor PE, Howells DW: Inhibiting BDNF expression by antisense oligonucleotide infusion causes loss of nigral dopaminergic neurons. Exp Neurol 192:226-234, 2005

30. Quirk GJ, Beer JS: Prefrontal involvement in the regulation of emotion: Convergence of rat and human studies. Curr Opin Neurobiol 16:723-727, 2006

31. Rosen JB, Schulkin J: From normal fear to pathological anxiety, Psychol Rev 105:325-350, 1998

32. Schwarzbold M, Diaz A, Martins ET, Rufino A, Amante LN, Thais ME, Quevedo J, Hohl A, Linhares MN, Walz R: Psychiatric disorders and traumatic brain injury. Neuropsychiatr Dis Treat 4:797-816, 2008

33. Steinbok P, Thompson G: Serum cortisol abnormalities after craniocerebral trauma. Neurosurgery 5:559-565, 1979

34. Slutsky I, Abumaria N, Wu LJ, Huang C, Zhang L, Li B, Zhao X, Govindarajan A, Zhao MG, Zhuo M, Tonegawa S, Liu G: Enhancement of learning and memory by elevating brain magnesium. Neuron 65:165-177, 2010
35. Tata DA, Anderson BJ: The effects of chronic glucocorticoid exposure on dendritic length, synapse numbers and glial volume in animal models: Implications for hippocampal volume reductions in depression. Physiol Behav 99:186-193, 2010

36. Taylor AN, Rahman SU, Tio DL, Gardner SM, Kim CJ, Sutton RL: Injury severity differentially alters sensitivity to dexamethasone after traumatic brain injury. J Neurotrauma 27:1081-1089, 2010

37. Tong W, Igarashi T, Ferriero DM, Noble LJ: Traumatic brain injury in the immature mouse brain: Characterization of regional vulnerability. Exp Neurol 176:105-116, 2002

38. Uysal N, Sisman AR, Dayi A, Aksu I, Cetin F, Gencoglu C, Tas A, Buyuk E: Maternal exercise decreases maternal deprivation induced anxiety of pups and correlates to increased prefrontal cortex BDNF and VEGF. Neurosci Lett 505:273-278, 2011

39. Walter B, Brust $P$, Füchtner $F$, Müller M, Hinz R, Kuwabara $H$, Fritz $H$, Zwiener $U$, Bauer R: Age-dependent effects of severe traumatic brain injury on cerebral dopaminergic activity in newborn and juvenile pigs. J Neurotrauma 21:1076-1089, 2004

40. Williams WH, Evans JJ, Fleminger S: Neurorehabilitation and cognitivebehaviour therapy of anxiety disorders after brain injury: An overview and a case illustration of obsessive compulsive disorder. Neuropsychol Rehabil 13:133-148, 2003

41. Woolf PD, Cox C, Kelly M, Nichols D, McDonald JV, Hamill RW: The adrenocortical response to brain injury: Correlation with the severity of neurologic dysfunction, effects of intoxication, and patient outcome. Alcohol Clin Exp Res 14:917-921, 1990 